\title{
DAMPAK PENAMBANGAN BATU BATA TERHADAP KONDISI FISIK LINGKUNGAN MASYARAKAT DESA KONTUMERE KECAMATAN KABAWO
}

\author{
Nofi Rahmawati ${ }^{1}$, La Ode Nursalam ${ }^{2}$ \\ ${ }^{1}$ Alumni Jurusan Pendidikan Geografi FKIP UHO \\ ${ }^{2}$ Dosen Jurusan Pendidikan Geografi FKIPUHO
}

\begin{abstract}
Abstrak: Adapun rumusan masalah (1) Bagaimana gambarantingkat penambangan Batu Bata Terhadap kondisi fisiklingkungan masyarakat Desa Kontumere Kecamatan Kabawo? (2)Bagaimana dampak penambangan batu bata terhadap kondisi fisik lingkungan masyarakat Desa Kontumere Kecamatan Kabawo? Tujuan penelitian ini adalah :(1) Untuk mengetahui gambaran kondisi fisik lingkungan Desa Kontumere Kecamatan Kabawo.(2) Untuk mengetahui dampak penambangan batu bata terhadap kondisi fisik lingkungan Desa Kontumere Kecamatan Kabawo.Informan penelitian ini adalah: a) informan kunci meliputi, Kepala Desa dan Pelaku Penambang batu bata di lokasi penelitian. b) informan utama berjumlah 30 orang yang terdiri dari masyarakat yang menetap di sekitan lokasi penambang batu bata. c) informan tambahan yaitu masyarakat umum yang tidak terlibat secara langsung maupun tidak langsung dalam penambangan batu batu dilokasi penelitian. Hasil penelitian ini menunjukan bahwa: a) dampak penambangan batu bata terhadap kondisi fisik lingkungan masyarakat di Desa Kontumere Kecamatan Kabawao adalah aspekkimia yang dikaji dalam penelitian ini adalah kondisi menurunnyakimia tanah dan pencemaran udara. 1) dampak kesehatan masyarakat terhadap penambangan baru bata di Desa Kontumere adalah dapat mengakibatkan kerusakan lingkungan yaitu pada saat proses pembakaran batu bata asap yang dihasilkan pembakaran kayu dapat menimbulakan ganguan pernapasan atau polusih sehiunnga udara yang dihirup hinga bagian paru - paru. 2) keadaan pendapatan masyarakat terhadap penambangan batu bata di Desa Kontumere.
\end{abstract}

Kata Kunci: Penambangan Batu Bata, Kondisi Fisik Lingkungan Masyarakat. 


\title{
THE IMPACT OF BRICK MINING ON PHYSICAL CONDITIONS IN THE NEIGHBORHOOD COMMUNITY OF KONTUMERE VILLAGE OF KABAWODISTRICT
}

\author{
Nofi Rahmawati ${ }^{1}$, La Ode Nursalam ${ }^{2}$ \\ ${ }^{1}$ Alumni Of Geography Education FKIP UHO \\ ${ }^{2}$ Lecturer Of Geography Education FKIP UHO
}

\begin{abstract}
The formulation of the problem (1) What is the description of the brick extraction level of the environmental physical conditions of the Kontumere village community in Kabawo District? (2) What is the impact of brick mining on the physical condition of the profiled village community of Kabawo sub-district? The objectives of this research are: (1) To determine the physical condition of the village of Kontumere, Kabawo District. (2) Determine the impact of brick quarrying on material conditions in Kontumere village, Kabawo district. The informants for this study were: a) Key informants included, village chief and brick miners at the research site. (b) The main informants numbered 30 and consisted of persons who had settled around the location of the brick miners. (c) additional informants, ie the general public, who did not participate directly or indirectly in the extraction of bricks from the research site. The results of this study indicate that: a) the impact of brick extraction on the physical condition of the community in Kontumere village, Kabawo sub-district, the chemical aspect studied in this study is the degradation status of soil chemistry and air pollution. 1) The impact of public health on brick extraction in the village of Kontumre can lead to environmental damage, especially when the combustion process of the smoke bricks produced by burning wood can cause respiratory problems or solutions for the air to be sucked in by the lungs. 2) the state of the community's income against the exploitation of bricks in the village of Kontumere.
\end{abstract}

Keywords: Exploitation of the brick, physical environment, conditions of society.

\section{PENDAHULUAN}

Pembanguan ekonomi Indonesia harus menghadapi kenyataan dengan masih luasnya kemiskinan, terutama di wilayah pedesaan. Kemiskinan merupakan beban bagi warga yang menyandangnya. Kemiskinan merupakan tanggung jawab semua elemen. Pembangunan pedesaan adalah sesuatu strategi pembangunan yang dirangsang untuk meningkatkan kehidupan sosial dan ekonomi dari kelompok khusus masyarakat, yaitu masyarakat di pedesaan. Pembangunan pedesaan bertujuaan untuk mengurangi kemiskinan, sehinga usaha ini harus dirancang secara jelas dan tegas kearah peningkatan produksi dan produktivitas (Safitri,2012:2).

Pada dasarnya pemerintah terus berusaha membangun system perekonomian bangsa untuk memenuhi tingkat kesejahteraan masyarakat. Dalam membangun berbagi sektor, pembangunan sektor ekonomi sebaiknya lebih

Nofi Rahmawati, La Ode Nursalam 
dikedepankan karena masalah ekonomi ini memegang perana penting dalam kehidupan masyarakat, apalagi masyarakat yang berdomisili di kawasan perdesaan seperti yang terdapat di Kecamatan Kabawo Kabupaten Muna.

Suatu kegiatan interaksi antara guru dan murid dimana akan diakhiri dengan proses evaluasi pembelajaran (Dimyati dan Mudjiono, 2006:3). Proses pembelajaran juga berarti suatu proses terjadinya interaksi antara pelajar yang berlangsung di lokasi tertentu dan dalam jangka satuan waktu. (Hamalik, 2006:162)

\section{Degradasi lingkungan dapat} diartikan sebagai penurunan kualitas lingkungan yang di akibatkan oleh kegiatan pembangunan yang di cirikan oleh tidak berfungsinya secara baik komponenkomponen lingkungan sebagaimana mestinya. Degradasi lingkungan pada dasarnya di sebabkan oleh adanya intervensi atau campur tangan manusia yang berlebihan terhadap keberadaan lingkungan secara alamiah. Degradasi lingkungan yang di bahas dalam modul ini lebih di fokuskan pada degradasi fungsi lahan dan tanah secara umum sebagai akibat intervensi manusia dalam proses pembangunan. Degradasi lingkungan dapat terjadi akibat pemanfaatan lahan dan masuknya bahan-bahan pencemar berbentuk padat dan cair kelingkungan yang mana bahan-bahan ini bukan merupakan bagian dari komponen lingkungan asli. Degradasi lingkungan dapat pula terjadi akibat proses eksploitasi terhadap lahan dan tanah, seperti yang terjadi pada proses penambangan timah, emas, batu bara dan lain sebagainya. Secara alami tanah hanya akan mengalami pencemaran apabila terjadi erosi, namun pencemaran alami ini selalu di imbangi oleh proses pelapukan produk alami dan pembentukan tanah yang baru.

Perbedaan kualitas tanah pada umumnya di nilai dari kondisi lapisan humus hasil pelapukan dan pembusukan sisa-sisa tanaman di bagian permukaan tanah. Semakin beragam organisme hidup yang terdapat di permukaan tanah, semakin berkualitas tanah tersebut. Degradasi lingkungan yang sering di jumpai anatara lain: benturan anatara dua kepentingan itupun masih kurang tepat karena yang tercermin dari benturan tersebut hanyalah kegiatan yang menimbulkan dampak negatif.

Tambang merupakan salah satu kegiatan ekonomi untuk meningkatkan kesejahteraan dan kemakmuran masyarakat dengan memanfaatkan sumber daya alam, sumber daya manusia, dan lain-lain. Dengan adanya tambang diharapkan mampu meningkatkan taraf hidup masyarakat. Tambang melibatkan berbagai komponen agar dapat menunjang roda keberhasilan tambang tersebut. Salah satu komponen tersebut adalah ketersediaan bahan baku yang akan diolah menjadi bahan siap pakai. Bahan baku yang akan diolah cenderung didapatkan dari alam. Semakin bertambahnya masyarakat pada suatu wilayah, maka semakin maju pula proses suatu tambang untuk menyediakan barang atau jasa yang diperlukan masyarakat. Hal ini juga akan memberikan dampak langsung terhadap alam dan lingkungan. Salah satu kebutuhan masyarakat adalah kebutuhan tempat tinggal/rumah layak huni.Salah satu bahan baku rumah yang paling dibutuhkan oleh masyarakat adalah batu bata.

Batu bata (batu merah) merupakan salah satu bahan baku rumah/tempat tinggal yang diproduksi dari tanah liat dan air. Prosesnya pun sangat sederhana, tanah liat dicampurkan dengan air sampai halus dan lembut, kemudian dicetak pada suatu wadah membentuk model yang diinginkan, lalu melalui tahapan pengeringan dan proses terakhir dibakar untuk menguatkan materialnya tersebut. Dengan proses yang sederhana tersebut, masyarakat cenderung mengeksplotasi tanah sebagai bahan baku 
indutri batu bata (batu merah) untuk memproduksinya. Lubang-lubang bekas galian tanah sebagai bahan baku produksi batu bata tersebut justru menjadi masalah tersendiri bagi lingkungan disekitarnya. Salah satu contoh dampak negatif dari hal tersebut adalah berkurangnya lahan masyarakat untuk bercocok tanam, dan pencemaran lingkungan. Asap tambang juga dalammelakukan produkdi batu bata tersebut cenderung mencemari udara.

Sehingga dengan demikian penggunaan lahan di Desa Kontumere terdiri dari pertanian seluas 10000 ha seluruhnya merupakan lahan pertanian dan perkebunan tanah kering seluas 9000 ha terdiri dari perkarangan/pembangunan seluas 7000 ha tanah keperluan Fasilitas Umum seluas 5000 ha (Kecamatan Kabawo dalam Angka Tahun 2012).

Alih fungsi lahan pertanian yang terjadi menyebabkan dan menurunnya kualitas lingkungan yang pada gilirannya berdampak sistematik pada ekosistem secara abiotik maupun biotik karena komponen fisik telah berubah. Dengan fakta di atas para penambang batu bata tetap melaksanakan kegiatan pertambangan batu bata di Kecamatan Kabawo tidak mengindahkan tentang hal-hal yang dapat menimbulkan kerusakan lingkungan, karena lokasi tambang adalah lahan pertanian.

Lingkungan merupakan segala sesuatu yang terdapat disekitar manusia, dan saling berinteraksi dengan manusia itu sendiri, baik makhluk hidup maupun makhluk tak hidup. Lingkungan dan alam cenderung menyediakan segala sesuatu kebutuhan tambang untuk memenuhi kebutuhan masyarakat. Salah satu wilayah di Sulawesi Tenggara yang melaksanakan aktifitas tambang batu bata terdapat di desa Kontumere Kecamatan Kabawo Kabupaten Muna. Banyaknya Tambang di desa tersebut menjadikan Desa kelihatan kumu, jalanan dalam Desa jadi kotor, sumur masyarakat mulai berwarna merah dan lainlain.

Lingkungan adalah suatu media di mana makhluk hidup tinggal, mencari, dan memiliki karakter serta fungsi yang khas yang mana terkait secara timbal balik dengan keberadaan makhluk hidup yang menempatinya, terutama manusia yang memiliki peranan yang lebih kompleks dan ril. Menurut Elly M. Setiadi dalam Rusdiana, 2012: 140.

Pertambangan adalah sebagian atau seluruh tahapan kegiatan dalam rangka penelitian, pengelolaan dan pengusahaan mineral atau batu bara atau unsur alam lainnya yang dikelolah untuk menghasilkan suatu barang dan jasa yang meliputi penyelidikan umum, eksplorasi, studi kelayakan, konstruksi, penambangan, pengolahan dan pemurnian, pengangkutan dan penjualan, serta kegiatan pasca tambang yang dilakukan oleh golongan masyarakat pada umumnya atau oleh pemerintah (Supardi, 2011: 22).

Batu bata merupakan salah satu elemen (material) pendukung dalam pendirian sebuah bangunan, terbuat dari humus dan tanah liat. Bahan utama batu bata adalah tanah dan air. Bentuk dan ukuran tanah bervariasi.(Subandi, 2013: 14).

Defenisi lingkungan adalah segala sesuatu yang ada di sekitar manusia serta mempengaruhi kehidupan manusia baik secara langsung maupun tidak langsung. Lingkungan di bedakan menjadi 2 yaitu: lingkungan biotik dan lingkungan abiotik. Lingkungan biotik adalah lingkungan yang hidup, misalnya tanah dan pepohonan. Sementara lingkungan abiotik adalah mencakup benda-benda yang tidak hidup seperti rumah, gedung dan meja.

Geografi lingkungan adalah ilmu geografi yang mempelajari tentang lingkungan hidup di sekitar manusia baik langsung maupun tidak langsung. Bidang 
ilmu Geografi pada dasarnya mempelajari berbagai komponen fisik muka bumi, mahluk hidup (tumbuhan, hewan dan manusia) di atas muka bumi, Kehidupan Manusia tidak bisa dipisahkan dari lingkungannya.

Lingkungan adalah suatu media di mana makhluk hidup tinggal, mencari, dan memiliki karakter serta fungsi yang khas yang mana terkait secara timbal balik dengan keberadaan makhluk hidup yang menempatinya, terutama manusia yang memiliki peranan yang lebih kompleks dan ril. Menurut Elly M. Setiadi dalam Rusdiana, 2012: 140, bahwa lingkungan hidup adalah kesatuan ruang dengan semua benda, daya, keadaan, dan makhluk hidup, termasuk di dalamnya manusia dan perilakunya. Lingkungan hidup tidak bisa dipisahkan dari ekosistem atau sistem ekologi. Ekosistem adalah satuan kehidupan yang terdiri atas suatu komunitas makhluk hidup (dari berbagai jenis) dengan berbagai benda mati yang membentuk suatu sistem. Manusia adalah bagian dari ekosistem.

Lingkungan fisik adalahkeadaan di sekitar rumah kita seperti suhu udara, pencahayaan, suara, penghawaan ruangan, kebersihan dan sikap kerja yang mempengaruhi masyarakat dalam menjalankan pekerjaannya. Menjalankan tugas - tugas yang dibebankan (Moe kijat, 1995). Sedangkan menurut Gie (2000) lingkungan fisik merupakan segenap faktor fisik yang bersama-sama merupakan suatu suasana fisik yang meliputi suatu tempat kerja.

Leavitt (1997) mendefinisikan lingkungan sebagai sebuah dunia tempat tinggal kita yang relatif masih lapang, yang masih jarang baik penduduknya maupun organisasi yang ada didalamnya. Menurut Ahyari (1986) secara umum lingkungan kerja didalam perusahaan merupakan lingkungan dimana para karyawan melaksanakan tugas dan pekerjaan seharihari. Kartono (1989) mengatakan bahwa lingkungan kerja adalah kondisi - kondisi material dan psikologis yang ada dalam perusahaan dimana karyawan tersebut bekerja.

Manusia sebagai mahluk sempurna tetap tidak luput dari kekurangan, dalam arti segala kemampuannya masih dipengaruhi oleh beberapa faktor. Faktor-faktor tersebut berasal dari diri sendiri (intern), dapat juga dari pengaruh luar (ekstern). Salah satu faktor yang berasal dari luar adalah kondisi fisik lingkungan kerja yaitu semua keadaan yang terdapat di sekitar tempat kerja seperti temperatur, kelembapan udara, sirkulasi udara, pencahayaan, kebisingan, getaran mekanis, bau-bauan, warna dan lain-lain. Hal-hal tersebut dapat berpengaruh secara signifikan terhadap hasil kerja manusia (Wignjosoebroto, 1995).

Soemarwoto (2009) mengartikan dampak adalah suatu perubahan yang terjadi sebagai akibat suatu aktivitas. Aktivitas tersebut dapat bersifat alamiah baik fisik, kimia maupun biologi. Misalnya semburan asap beracun merapi merupakan aktivitas alam yang bersifat kimia, gempa bumi adalah aktivitas dalam yang bersifat fisik, dan pertumbuhan masal eceng gondok adalah aktivitas alam biologi. Dampak pembangunan menjadi masalah karena perubahan yang di sebabkan oleh pembangunan selalu lebih luas dari pada yang menjadi sasaran dari pembangunan tersebut, secara umum dalam AMDAL dampak pembangunan di artikan sebagai perubahan yang tidak di rencanakan yang di akibatkan oleh aktivitas pembangunan.

Di dalam AMDAL ada dua jenis batasan tentang dampak: 1). Dampak pembangunan terhadap lingkungan sebelum ada pembangunan dan yang di perkirakan akan ada setelah ada pembangunan; 2). Dampak pembangunan terhadap lingkungan ialah perbedaan antara kondisi lingkungan yang di perkirakan aka nada tanpa adanya pembangunan dan yang di perkirakan ada karena adanya pembangunan tersebut ( Soemarwoto, 1997) 
Mac Iver Page dalam Soerjono Soekanto (1990 : 26) mengatakan bahwa "suatu system dan suatu kebiasaan dan tata cara dari wewenang, dari kerja sama antara berbagai kelompok dan pengelompokan dari pengawasan tingkah laku serta kebebasan - kebebasan manusia. Keseluruhan yang berubah - ubah masyarakat merupakan jalinan hubungan sosial dan masyarakat selalu berubah ubah".

\section{METODE PENELITIAN}

\section{Waktu dan Tempat Penelitian}

Penelitian ini dilaksanakan pada Bulan Maret 2018, bertempat di Desa Kontumere Kecamatan Kabawo Kabupaten Muna.

\section{Jenis Penelitian}

Jenis penelitian ini adalah penelitian deskriptif kualitatif yaitu mendeskripsikan secara alamiah mengenai dampak penambangan batu bata terhadap kondisi fisik lingkungan masyarakat Desa Kontumere Kecamatan Kabawo Kabupaten Muna.

\section{Informan Penelitian}

Dalam penelitian kualitatif tidak dimaksudkan untuk membuat generalisasi dari hasil penelitiannya. Oleh karena itu, pada penelitian ini tidak dikenal adanya populasi (Suyanto, 2015: 171). Subyek dalam penelitian ini ditentukan secara sengaja. Subyek penelitian menjadi informan yang yang akan memberikan berbagai informasi yang diperlukan selama proses penelitian. Informan merupakan orang yang benar-benar mengetahui suatu persoalan atau permasalahan tertentu. Darinyalah peneliti memperoleh informasi yang jelas, akurat dan terpercaya, baik berupa pernyataan, keterangan-keterangan, serta data-data yang dapat membantu dalam memenuhi permasalahan. Informan penelitian (Suyanto, 2005: 172) meliputi beberapa macam, yaitu: 1). Informasi kunci yang merupakan mereka yang mengetahui dan memiliki berbagai informasi pokok yang diperlukan dalam penelitian, 2) informan utama merupakan masyarakat yang terlibat langsung dalam interaksi sosial yang diteliti, 3) informan tambahan merupakan mereka yang dapat memberikan informasi walaupun tidak langsung terlibat dalam interaksi sosial yang diteliti.

Berdasarakan uraian diatas, maka peneliti menentukan informan dengan menggunakan teknik purposiv sampling, yaitu pengambilan informan secara sengaja dan informan yang digunakan adalah mereka yang benar-benar paham dan dapat dipercaya menjadi sumber data yang valid dan mengetahui masalah secara mendalam mengenai permasalahan yang diteliti (Sutopo, 2002: 22).

\section{Teknik Pengumpulan Data}

Teknik pengumpulan data dalam penelitian ini menggunakan :

\section{Observasi}

Sutriano Hadi (1989) dalam Sugiyono (2012) mengemukakan bahwa observasi merupakan suatu proses yang kompleks, tersusun dari berbagai proses biologis dan psikologis. Diantara yang terpenting adalah proses pengamatan dan ingatan fenomena atau gejala yang terjadi di lapangan, dalam hal ini mengamati langsung ke lokasi penelitian terhadap dampak penambangan batu bata terhadap degradasi lingkungan di lokasi penelitian.

\section{Wawancara}

Wawancara merupakanpercakapan dengan maksud tertentu. percakapan itu dilakukan oleh dua pihak, yaitu pihak pewawancara yang ingin mendapatkan data dan pihak yang diwawancara yang ingin memberikan data pengamatan.

\section{Dokumentasi}


Dokumentasi merupakan teknik pengumpulan data dengan cara memperoleh informasi dari media tertulis, atau dokumen yang berada dilokasi penelitian.

\section{Sumber Data}

Sumber data dalam penelitian ini adalah sebagai berikut:

1. Data primer adalah data yang diperoleh secara langsung dari lokasi penelitian tanpa adanya perantara seperti pernyataan masyarakat mengenai dampak industri batu bata terhadap degradasi lingkungan di lokasi penelitian.

2. Data sekunder adalah data yang diperoleh melalui sumber yang telah disediakan seperti gambaran umum tentang lokasi penelitian.

\section{Teknik Analisis Data}

Teknik analisis data yang digunakan adalah deskriptif kualitatif, dimana penulis mendeskriptifkan hasil penelitian berdasarkan data yang didapatkan ketika penelitian. Variabel dalam penelitian ini diuraikan sebagai berikut: penambangan batu merah, pembuatan batu bata. Degradasi lingkungan yaitu: kerusakan lingkungan, kerusakan tanah, erosi, dan pencemaraan udara.

\section{Instrumen Penelitian}

Instrumen yang digunakan dalam penelitian ini yaitu menggunakan kamera sebagai alat untuk mendokumentasikan, dan menggunakan pedoman wawancara untuk mendapatkan data dari informan yang akan diwawancara.

\section{HASIL DAN PEMBAHASAN}

\section{Dampak Penambangan Batu Bata Terhadap Kondisi Fisik Lingkungan Masyarakat Desa Kontumere Kecamatan Kabawo.}

Berdasarkan hasil penelitian bahwa kegiatan penambangan Batu bata sudah lama dilakukan oleh masayarakat Desa Kontumere Kecamatan Kabawo Kabupaten Muna, namun penambangan ini mulai berkembang pada tahun 2000 .

Berdasrkan hasil penelitian di lapangan menunjukan di Deasa Kontumere Kecamatan Kabawo Kabupaten Muna, bahwa masyarakat mulai menekuni kegiatan ekonomi nonpertanian yaitu kegiatan penambangan batu bata di daerah ini merupakan hasil budidaya masyarakat setempat dalam usaha untuk keluar dari keterpurukan ekonomi dan meningkatkan taraf hidup masyarakatnya khususnya dalam bidang ekonomi. Hal ini dikarenakan, apabila masyarakat hanya bergantung dari penghasilan bidang pertanian saja tidak cukup untuk memenuhi kebutuhan rumah tangga yang semakin hari semakin meningkat. Berdasrkan beberapa hasil wawancara sebgai berikut:

Berdasarkan wawancara yang di ungkapkan oleh Bapak La Marruwia salah satu pemilik penambangan batu bata di Desa Kontumere Kecamatan Kabawo Kabupaten Muna, diungkapkan bahwadi Desa Kontumere Kecamatan Kabawo jumlah pengrajin batu bata terus mempengaruhi perkembangan ekonomi masyarakat dan umumnya tidak menghilangkan pekerjaan utama mereka sebagai petani, sebagaimana, mengatakan bahwa sekitar tahun 2000 jumlah pengrajin Batu bata terus meningkat disamping dalam usaha utamanya di bidang pertanian. Hal ini dikarenakan tingkat kehidupan sosial ekonomi yang semakin meningkat menyebabkan naiknya permintaan produksi barang di samping untuk meningkatkan penghasilan,(wawancara, 19 Mei 2018) . 
Jurnal Penelitian Pendidikan Geografi Volume 4. No 2 April 2019

Tabel 5.1 Jumlah Tenaga Kerja Dari 6 Penambang Batu Bata Desa Kontumere

\begin{tabular}{clccc}
\hline No. & \multicolumn{1}{c}{$\begin{array}{c}\text { Pemilik } \\
\text { Tambang Batu } \\
\text { Bata }\end{array}$} & \multicolumn{2}{c}{ Tenaga Kerja } & Jumlah \\
& \multicolumn{1}{c}{ Nama } & Laki - Laki & Perempuan & \\
\cline { 2 - 4 } & La Habini & 5 & 2 & 7 \\
\hline $\mathbf{2}$ & La Ita & 5 & - & 5 \\
\hline $\mathbf{3}$ & La Mursali & 5 & - & 5 \\
\hline $\mathbf{4}$ & La Maruwia & 4 & - & 4 \\
\hline $\mathbf{5}$ & La Ida & 4 & 1 & 5 \\
\hline $\mathbf{6}$ & Wa Rina & 3 & 1 & 4 \\
\hline
\end{tabular}

Sumber Data: Wawancara RespondenTahun 2018

Pengrajin penambangan batu bata di Desa Kontumere semakin bertambah dari satu pengrajin menjadi enam pengrajin batu bata, peningkatan ini terjadi akibat banyaknya permintaan akan batu bata untuk keperluan pembangunan, sehingga dapat membuka peluang atau lowongan usaha bagi masyarakat yang hanya meningkatkan kehidupannya dibidang pertanian.

Perkembangan usaha pembuatan batu bata di Desa Kontumere di dorong oleh ketersediaan bahan baku yang cukup memadai. Dari hasil pengamatan dilapangan menunjukan bahwa di daerah Desa Kontumere pada mulanya memiliki topografi atau kondisi tanahnya tidak merata, yaitu sebagian besar di Desa Kontumere lebih tinggi dataranya lahan tanah pertanian. Sehingga letak geografis dan mata pencaharian penduduk berperan penting terhadap pertumbuhan dan perkembangan perekonomian daerah.

\section{Perkembangan}

pusat-pusat pembuatan penambangan didaerah memiliki potensi sumber alam akan lebih ditingkatkan dengan sumber daya manusia dan sumber-sumber pembaruan lainnya. Dalam hubungan ini keterkaitan antara penambangan besar dan penambangan kecil baik di luar maupun antar daerah (Kansil, 1986).

Berdasarkan penelitian dilapangan, penulis memperoleh keterangan bahwa pada mulanya usaha pembuatan batu bata di Desa Kontumere Kecamatan Kabawo hanya dikerjakan oleh beberapa warga saja. Warga masyarakat yang melalui pembuatan usaha batu bata ini sebagian besar masyarakat Desa Kontumere dari berbagai dusun kemudian setelah mereka bisa, dan mulai mempraktekan usaha membuat sendiri. Usaha membuat batu bata ini mulanya hanya dilakukan di daerah sekitar pekarangan rumah, dengan mendirikan 
sebuah bhansal rumah gubuk di sekitar pekarangan. Pada awal pembuatanya pekerjaan ini merupakan kegiatan sampingan dan usaha utama yaitu pertanian.

Berdasarkan wawancara yang di ungkapkan oleh bapak La marwia salah satu pemilik penambangan batu bata di Desa Kontumere Kecamatan Kabawo Kabupaten Muna, diungkapkan bahwa'hasil pengamatan menunjukan bahwa usaha pembuatan batu bata di Desa Kontumere mulai memperlihatkan pertumbuhan secara nyata sebagai system mata pencaharian masyarakat Desa Kontumere pada tahun 1996. Secara tidak langsung usaha ini hampir menggeser sistem mata pencaharian sebagai warga masyarakat Desa Kontumere dari sektor pertanian kesektor penambangan. Akan tetapi, masyarakat Desa Kontumere tetap mempertahankan sektor pertanian sebagai sistem mata pencaharian utama mereka disamping membuat penambangan batu bata ini. Perkembangan yang nyata ini terlihat dari banyaknya para pengrajin - pengrajin baru yang mengikuti usaha dalam membuat batu bata. Jumlah produksi batu bata di Desa Kontumere setiap tahunnya semakin bertambah, (wawancara, 19 Meii 2018).

Kegiatan dalam pengelolaan sumber daya alam banyak yang mengakibatkan kerusakan lingkungan dan ekosistem. Untuk mengetahui kerusakan lingkungan diperlukan adanya kriteria baku mutu lingkungan. Salah satu kerusakan lingkungan yang terjadi berada di wilayah Desa Kontumere di salah satu Kecamatan yaitu Kecamatan Parigi. Kerusakan lingkungan hidup diakibatkan penambangan tanah di lahan pertanian untuk kegiatan penambangan batu bata.

Identifikasi dampak penambangan batu bata merupakan langkah awal dalam menentukan komponen lingkungan apa saja yang terkena dampak. Sedangkan perkiraan dampak kita menentukan besarnya dampak yang akan terjadi, baik secara kualitatif maupun kuantitatif. Dalam perkiraan dampak ini, bila besarnya melebihi atau di bawah baku mutu yang telah ditentukan dianggap dampak penting.

Informasi mengenai dampak kerusakan lingkungan akibat penambangan batu bata berawal dari alih fungsi lahan pertanian dengan penebangan - penebangan vegetasi penutup lahan untuk mendukung aktivitas penambangan batu bata. Akibat penebangan vegetasi terjadi perubahan bentang lahan dapat merubah struktur tanah. Hilangnya vegetasi sebagai penutup lahan untuk menangkap air hujan. Dampaknya, wilayah tersebut akan semakin kering. Berkurangnya vegetasi di sekitar lokasi penambangan batu bata menyebabkan berkurangnya kandungan oksigen di udara sehingga suhu di wilayah tersebut menjadi semakin tinggi dan menyebabkan tanah menjadi semakin labil.

Dampak kerusakan lainnya terkait penambangan batu bata di Desa Kontumere dapat berupa rusaknya permukaan, bekas penambangan batu bata yang tidak teratur, hilangnya lapisan tanah yang subur, dan sisa ekstraksi (tailing) yang akan berpengaruh pada reaksi tanah dan komposisi tanah. Sisa ekstraksi ini bisa bereaksi sangat asam atau sangat basa, sehingga akan berpengaruh pada degradasi kesuburan tanah.

Penambangan batu bata disamping akan merusak tata air juga akan terjadi kehilangan lapisan tanah bagian atas (top soil) yang relatif lebih subur, dan meninggalkan lapisan tanah bawahan (sub soil) yang kurang subur, sehingga lahan pertanian akan menjadi tidak produktif (Alamprabu, 2007).

Kerusakan tanah terjadi karena hampir semua lokasi penelitian teknik penambangan masih belum benar, yaitu dengan cara memotong tebing secara vertikal sehingga kestabilan lereng akan 
kecil. Akibatnya bisa menyebabkan terjadinya longsoran dan membahayakan penambang. Akibat lain adalah pada saat reklamasi akan mengalami kesulitan dan membutuhkan biaya yang lebih besar. Selain itu, tingkat erosi akan semakin besar sehingga akan mengakibatkan sedimentasi yang besar. Kedalaman tebing galian mempunyai kisaran 1-5 meter.

Tebing galian yang dalam seperti itu akan membahayakan penambang maupun berpotensi terjadinya erosi dan tanah longsor. Di lokasi penambangan batu bata telah di jumpai pula lubang - lubang bekas galian yang cukup dalam. Kondisi ini membahayakan masyarakat terutama saat musim hujan, lubang - lubang bekas galian ini akan terisi air sehingga tergenang dan sangat berpotensi menjadi sarang nyamuk. Luas lubang galian berkisar antara $20 \times 12$ meter hingga 50 × 25 meter. Luas lubang galian ini berpengaruh terhadap luasan genangan yang terjadi saat musim hujan.

Berdasarkan kondisi lingkungan fisik dampak erosi terhadap penambangan batu bata di lokasi penelitian akan menyebabkan hanyutnya partikel - partikel tanah dan sangat berpengaruh terhadap struktur tanah. Rusaknya struktur tanah oleh erosi di daerah lokasi penambangan batu bata di Desa Kontumere, akan menyebabkan mengecilnya pori-pori tanah, sehingga kapasitas infiltrasi menurun, dan aliran permukaan menjadi lancar ini dapat menyebabkan longsor. Penambangan batu bata di Desa Kontumere yang tidak mengindahkan konservasi tanah dan lahan, akan menyebabkan erosi yang di ikuti hilangnya bahan organik tanah. Hal ini menyebabkan berkurangnya air permukaan atau air hujan yang masuk ke dalam tanah. Akibatnya hujan yang jatuh dengan mudah terakumulasi di permukaan. Kehilangan unsur hara karena adanya erosi di lokasi penambangan batu bata akan menurunkan produktivitas lahan.
Selanjutnya penelusuran mengenai pencemaran udara berdasarkan pengamatan dilapangan proses pembakaran batu bata menggunakan kayu bakar yang di peroleh disekitar lokasi penelitian maupun di luar Desa Kontumere. Proses pembakaran batu bata membutuhkan waktu 1 - 3 hari. Lamanya proses pembakaran ini dapat meningatkan polusi udara $\left(\mathrm{NOx}\right.$ dan $\mathrm{CO}^{2}$ ) disekitar lokasi penambangan. Terjadi peningkatan polusi udara yaitu asap pada saat melakukan proses pembakaran batu bata menyebabkan kualitas udara di sekitar kawasan pembakaran menurun. Meningkatnya asap pembakaran dapat mengganggu pernapasan.

Berdasarkan wawancara yang di ungkapkan oleh bapak La Marwia salah satu pemilik penambangan batu bata di Desa Kontumere Kecamatan Kabawo Kabupaten Muna, diungkapkan bahwabegini nak, saya kasihtau, kalau proses pembakaran batu bata, dibakar pada malam hari bukan dibakar siang hari, kalau dibakar mulai siang hari sudah jelas akan mengganggu aktifitas masyarakat di sekitar sini, tapi kalau pembakaran dimulai malam hari sudah pasti tidak mengganggu orang disekitar sini, soalnya kalau malam tidak ada yang berakitifitas, jadi kalau tidak percaya nati kamtanya orang - orang sekita sini dek suapay kamu percaya, wawancara, 19 Mei 2018) .

Kerusakan lingkungan yang
ditimbulkan akibat adanya kegiatan
penambangan batu bata di Desa Kontumere,
temuan dilapangan mengenai degradasi
lingkungan akibat penambangan batu bata
ada beberapa hal yang dikaji dalam
pengedentifikasian permasalahan
lingkungan berdasarkan kondisi rona awal
lingkungan yaitu aspek fisik, kimia dan
biologi mengenai kondisi lingkungan hidup
terkait dengan ukuran kualitas lingkungan
dapat diuraikan sebagai berikut.
terkait dengan ukuran kualitas
dapat diuraikan sebagai berikut.

Nofi Rahmawati, La Ode Nursalam 
Berdasarkan pengamatan dilapangan bahwa tofografi tanah dilokasi penelitiansudah mengalami perubahan fisik lingkungan, hal ini dapat dilihat dari luasna area penambangan batu bata. Berdasarkan informasi penulis mengungkapkan bahwa sejak berdiri tahun 2000 luas area yang diusahakan penambang batu bata berkisar antara sampai $20 \mathrm{~m} \times 12 \mathrm{~m}$ sampai dengan $50 \mathrm{~m} \times 25 \mathrm{~m}^{2}$ dengan rata-rata kedalaman antara 4-5 m. Lokasi penambangan batu bata di Desa Kontumere tersebar di dua dusun. Luas lahan tambangnya sempit seperti lokasi di dusun I batu bata yang mampu ditambang mencapai $80 \mathrm{~m}$ per-hari. Sedangkan pada lokasi penambangan yang lebih luas seperti lokasi di dusun II rata-rata volume produksinya mencapai $150 \mathrm{~m}^{3}$. Hal ini disebabkan oleh tingginya intensitas penambangan yang dilaksanakan karena aktivitas ini hampir berlangsung setiap hari terutama pada musim kemarau.

Sehingga secara umum pengaruh penambangan batu bata sudah tidak mampu lagi mendukung aktifitas dan kegiatan sesuai dengan peruntukannya. Baik itu untuk peruntukan pemukiman, pertanian ataupun perkebunan. Salah satu alasan pula yang mendasari usaha pembuatan batu bata di Desa Kontumere, mulanya dikembangkan sebagai suatu usaha pemanfaatan lahan pertanian memanfaatkan tanahnya untuk membuat batu bata.

Keterangan yang sama juga disampaikan oleh bapak La Habini dalam keteranganya tentang lahan berkurang ketika membuak usaha penamabangan batu bata. Dalam penjelasnya mengungkapkan bahwa'pengamatan di lapangan dan hasil wawancara menunjukkan bahwa keadaan yang mencolok di areal lahan pertanian dan perkebunan yang dijadikan usaha pembuatan batu bata di Desa Kontumere memperlihatkan ketidak seimbangan kontur tanah bila dibandingkan dengan keadaan lahan pertanian sekitar kurang lebih 20 tahun yang lalu. Bahwasanya keadaan tanah sekitar tahun 90-an sampai 2000-an yang kemudian dimanfaatkan sebagai bahan baku pembuatan batu bata akhirnya menyebabkan kontur tanah yang semula keadaanya lebih tinggi diantara jalan raya yang melaluinya sekarang menjadi sejajar bahkan lebih rendah daripada sebelumnya, (wawncara, 19 Mei 2018).

Dalam pembangunan penambangan akan selalu diusahakan untuk mencegah pencemaran dan perusakan lingkungan hidup, pemborosan penggunaan sumber daya alam, serta menghindarkan rangsangan bagi tumbuhnya pola konsumsi mewah. Pembangunan penambangan di Indonesia akan ditunjang oleh peningkatan pelaksanaan kebijakan mengenai pengutamaan pemakaian hasil produksi penambangan sendiri baik penambangan besar maupun penambangan kecil/ rumah tangga (Kansil, 1986: 107).

Keterangan yang sama juga disampaikan oleh bapak La Habini dalam keteranganya tentang kedalaman lubang galian untuk pengambilan bahan pembuatan batu bata. Dalam penjelasnya mengungkapkan bahwa" "batasan penggunaan tanah tersebut antara 4 meter sampai 5 meter kedalam dari ukuran rata tanah. Apabila telah mencapai kedalaman tersebut maka para pengrajin batu bata mengambil tanah dari lahan yang baru. Selain itu juga penggunaan tanah yang melebihi batas kedalaman tanah tersebut diatas ternyata tidak bagus kualitas tanahnya sebagai bahan baku pembuatan batu bata (, wawancara, 19 Mei 2018).

Dampak mengenai bahaya longsor berdasarkan pengamatan penambangan batu bata ditemukan kedalaman penggalian tanah sampai 5 meter sehingga dengan adanya aktivitas ini dapat berpotensi meningkatkan ancaman tanah longsor. Dilihat dari teknik penambangan batu bata, dimana para pengarajin batu bata menggali secara 
terbuka (open pit) tidak secara berjenjang (trap-trap), namun asal menggali saja dan nampak bukan penggalian tidak teratur dan membentuk dinding yang lurus dan menggantung yang sangat rentan runtuh (longsor).

Selanjutnya dari hasil survey dilokasi penelitian areal bekas penggalian dibiarkan begitu saja dan terlihat gersang berpotensi mengalami erosi dipercepat karena tidak adanya vegetasi penutup tanah. Sehingga mengakibatkan terjadi genangan air yang berada di dekat lokasi penambanagn batu bata juga terlihat mengalami erosi pada tebing sisi kanan dan kirinya. Selain itu telah terjadi pelebaran pada dinding tebing penggalihan, bahkan penggalian yang terlalu dalam membetuk kolam pada permukaan tanah yang kedalamannya mencapai 5 meter.

Kedalaman tanah yang berbeda dapat menimbulkan permasalahan kemampuan menyimpan air bagi lahan lahan pertanian disekitar yang tidak ditambang. Selanjutnya hilangnya top soil tanah sehingga kesuburan tanah pada lokasi galian batu bata menjadi berkurang sehingga tanah menjadi tidak subur. Tanah yang dikembalikan sebagai tanah penutup lahan bekas penambangan tidak ada ditemui di lokasi penelitian yang diamati, sehingga standar minimal tanah yang harus dikembalikan sesuai dengan standar yang telah ditetapkan dalam KepMen LH No 43 Tahun 1996 tidak terpenuhi, sehingga dapat dinyatakan bahwa di lokasi areal penambangan batu bata di Desa Kontumere yang diamati sudah mengalami kerusakan, sehingga tidak bisa difungsikan sesuai dengan peruntukannya.

Aspek Kimia yang dikaji dalam penelitian ini adalah kondisi menurunnyakimia tanah dan pencemaran udara. Tanahsebagai ruang untuk menyimpan zat - zathara terutama sifat kimia tanah secaramikro yang dibutuhkan tumbuhan akanmengalami penurunan kualitas. Hilangnyaunsur hara dapat menyebabkan lahan yang di jadikan penambangan batu bata dapat menyebabkan tanah tidak subur. HasilWawancara penulis dengan Kepala Desa Kontumeremengungkapkan bahwa kualitas tanah dilokasi penambangan batu bata sudah tidaksubur hal ini diakibatkan olehberkurangnya sifat - sifat kimia mikro tanah. Berkurangnya unsur kimia mikro tanah diperpara ketika musim penghujan tiba dan terjadi erosi sehingga tanah tidak mampu lagi mempertahankan kesuburannya karena sebagian vegetasi penutup tanah sudah hilang.

Keterangan yang disampaikan oleh bapak La Habini dalam keteranganya tentang mepengaruhi kodeisi air bersih yang dipakaya oleh masyarakat sekitar adanya usaha penamabangan batu bata. Dalam penjelasnya mengungkapkan bahwa

\footnotetext{
'"hasil wawancara dan pengamatandi lapangan terkait dengan dampak penambangan batu bata yang terkait dengan lapisan permukaan tanah terutama top soil tidak di manfaatkan kembali sebagai penutup lahan sehingga akan menjadi limbah. Ketika musim hujan lapisan tanah ini akan terakumulasi kedalam lubang galian sehingga menjadi limbah dan akan menyebabkan terjadinya sedimentasi. Dampak penambangan batu bata di lokasi penelitian belum mempengaruhi kondisi kualitas sumber air masyarakat. Umumnya sumber air masyarakat Desa Kontumere berasal dari sumur gali yang berasal dari bantuan pemerintah melalui PNPM Mandiri perdesaan. Berdasarkan hasil survey kondisi sumur di Lokasi peneliian belum mengalami kekeruhan air dan hanya terjadi penurunan jumlah air pada saat musim kemarau, (wawancara, 19 Meii 2018).
} 
Kondisi aspek Biologi yang diamati dilapangan akibat dampak penambangan batu bata adalah kondisi vegetasi. Keadaan vegetasi yang terdapat di lokasi penelitian dan sekitarnya terdiri atas dulunya lahan pertanian, kebun campuran dan tanaman pekarangan. Identifikasi vegetasi di lokasi penelitian adalah tumbuhan berkayu seperti jambu mete dan jenis kayu - kayuan lainnya memanfaatkannya sebagai pembakaran batu bata. Dengan adanya penambangan batu bata menyebabkan penebangan pohon kayu semakin berkurang. Areal penambangan batu bata yang ada di Desa Kontumere berada disekitaran tempat tinggal.

Dengan adanya penambangan batu bata di Desa Kontumere maka tidak mungkin lagi dapat dipungkiri bahwa pohon kayu (Jambu mete) di sekitaran tempat tinggal yang ada di Desa Kontumere berkurang. Sehingga dengan berkurangnya pohon kayu di sekitaran rumah akan berkurang fungsi pohon kayu, baik fungsi terhadap lingkungan. Hasil survey aspek fisik dan aspek biologi di areal tambang batu bata di Desa Kontumere Kecamatan Kabawo tahun 2018 di sajikan pada Tabel 5.2. Berdasarkan Tabel 5.2. bahwa kerusakan lingkungan yang terjadi akibat penambangan batu bata dapat dilihat dari aspek fisik dan hayati. Berdasarkan tofografi di lokasi penelitian kedalaman lubang galian berkisar antara $3-5$ meter sementara anjuran dari Keputusan menteri Lingkungan Hidup No 43 tahun 1996 maksimal 1 meter. Selanjutnya adalah dari aspek degradasi lahan bahwa lubang - lubang galian dibiarkan begitu saja tanpa mengembalikan tanah sebagai penutup lahan. Sedangkan vegetasi yang ada disekitaran penambangan batu bata tidak ditemukan adanya vegetasi sebagai penutupan lahan, yang ada hanya rumput yang tumbuh disekitar cekungan lubangan bekas penggalian.

Akibat yang ditimbulkan dengan tidak adanya tanah yang dikembalikan sebagai lahan penutup, menyebabkan tidak ditemuinya vegetasi, baik itu tanaman budidaya ataupun tanaman tahunan di lokasi penelitian. Berdasarkan KepMen LH No 43 tahun 1996, area bekas penambangan tanah liat di lokasi penelitian sudah mengalami kerusakan.

Menurut Widjaya (2010), kerusakan lahan bekas tambang tanah liat dapat dikategorikan menjadi 3, diantaranya adalah sebagai berikut. (1) Tingkat kerusakan ringan, yaitu apabila lahan bekas tambang hanya mengalami perubahan tofografi saja. (2) Tingkat kerusakan sedang, apabila lahan bekas tambang mengalami perubahan tofografi dan sumber daya hayati. (3) Tingkat kerusakan berat, apabila lahan bekas tambang mengalami perubahan tofografi, sumber daya hayati dan erosi. Berdasarkan hasil analisis di atas, tingkat kerusakan lingkungan akibat penambangan batu bata di Desa Kontumere Kecamatan Kabawo Kabupaten Muna sudah tingkat mengalami kerusakan sedang.

\begin{tabular}{cccc} 
& & \multicolumn{2}{c}{ Lokasi Pengamatan } \\
\cline { 3 - 3 } No. & Aspek Fisik Dan Hayati \\
& & \multicolumn{2}{c}{ Dusung } \\
\cline { 3 - 3 } & & & \\
\hline 1 & Topografi & I \\
\hline
\end{tabular}

a. Lubang Galian 
Jurnal Penelitian Pendidikan Geografi Volume 4. No 2 April 2019

\begin{tabular}{|c|c|c|c|}
\hline & Kedalaman & $5 \mathrm{~m}$ & $5 \mathrm{~m}$ \\
\hline & Jarak & $4 \mathrm{~m}$ & $5 \mathrm{~m}$ \\
\hline \multicolumn{4}{|c|}{ b. Dasar Galian } \\
\hline & Perbedaan relief dasar galian & $1,79 \mathrm{~m}$ & $1,83 \mathrm{~m}$ \\
\hline \multicolumn{4}{|c|}{ c. Dinding Galian } \\
\hline & Tebing & $4 \mathrm{~m}$ & $4 \mathrm{~m}$ \\
\hline \multirow[t]{2}{*}{2} & Tanah & & \\
\hline & $\begin{array}{l}\text { Tanah Yang Dikembalikan Sebagai } \\
\text { Penutup Bekas Galian Lahan }\end{array}$ & $\begin{array}{l}\text { Tidak } \\
\text { Ada }\end{array}$ & Tidak Ada \\
\hline \multirow[t]{3}{*}{3} & Vegetasi & & \\
\hline & $\begin{array}{l}\text { a. Tutupan Tanaman Budi } \\
\text { Daya }\end{array}$ & Ada & Ada \\
\hline & b. Tutupan Tanaman Tahunan & $\begin{array}{l}\text { Tidak } \\
\text { Ada }\end{array}$ & Tidak Ada \\
\hline
\end{tabular}

Keterangan yang sama juga disampaikan oleh bapak La Ita dalam keteranganya tentang pemmbuakaan usaha penamabangan batu bata sekitaran lahan pekarangan. Dalam penjelasnya mengungkapkan bahwa

" "kegiatan penambangan batu bata di Desa Kontumere yang mulanya dilakukan di sekitaran pekarangan rumah ternyata telah mengakibatkan dampak negatif. Olehnya itu, untuk mengatasi hal tersebut dilakukanya pemindahan lokasi. Selain itu, perkembangan sosial ekonomi masyarakat di Desa Kontumere yang semakin meningkat memperlihatkan bahwa usaha pembuatan batu bata dipandang tidak elok bila dilakukan disekitaran pekarangan rumah. Dari hasil keterangan yang diperoleh di lokasi penelitian, oleh Bapak La Ita mengatakan dengan adanya pemindahan lokasi penambangan batu bata agar tidak terjadi hal-hal yang tidak diinginkan karena kegiatan pembuatan batu bata ini adalah kegiatan yang berkelanjutan, (wawancara, 20 Mei 2018).

Kualitas lingkungan hidup di lokasi penambangan batu bata sebagian besar sudah mengalami perubahan fisik dan hayati. Olehnya itu perlu adanya kesadaran dari pengusaha batu bata untuk melakukan reklamasi lahan dengan menanam tanaman jangka panjang sebagai vegetasi penutupan lahan sehingga dapat dimanfaatkan kembali dalam peruntukan. Perkembangan lapangan pekerjaan di Desa Kontumere, dalam hal ini penambangan berkelanjutan adalah suatu upaya dan pendekatan dalam pemanfaatan sumber daya alam yaitu penambangan batu bata terhadap masyarakat sekarang tanpa 
mengurangi kemampuan untuk memenuhi kebutuhan mereka.

Pembangunan penambangan pada sektor usaha di bidang penambangan batubata merupakan suatu upaya masyarakatdalam meningkatkan pendapatankebutuhan hidup dan bila ditinjau dari segi ekonomi danpola kehidupan masyarakat sangatberhubungan langsung denganpeningkatan kebutuhan barang dan jasa.Penggunaan sumber daya alam secarabesar - besaran dengan mengabaikanlingkungan dapat mengakibatkan berbagaidampak negatif yang terasa dalam jangkapendek maupun dalam jangka panjang.

Salah satu masalah kerusakan lingkungan akibat penambangan batu bata adalah degradasi lahan yang besar, yang apabila tidak ditanggulangi secara cepat dan tepat akan menjadi lahan kritis sampai akhirnya menjadi gersang. Dalam langkah langkah penanggulangan dan pengelolaan lingkungan hidup berdasarkan Undang Undang Nomor 32 Tahun 2009 Tentang Perlindungan dan Pengelolaan Lingkungan hidup bahwa kerusakan lingkungan adalah perubahan langsung dan/atau tidak langsung terhadap sifat fisik, kimia, dan/atau hayati lingkungan hidup yang melampaui kriteria baku kerusakan lingkungan hidup. Pengertian kriteria baku kerusakan lingkungan hidup adalah ukuran batas perubahan sifat fisik, kimia, dan atau hayati yang dapat ditenggang oleh lingkungan hidup tetap melestarikannya.

Kerusakan lingkungan hidup salah satunya disebabkan oleh kegiatan penambangan. Penambangan berdasarkan pasal 1 butir 2 Undang - Undang Nomor 3 Tahun 2014 Tentang penambangan adalah seluruh bentuk kegiatan ekonomi yang mengolah bahan baku dan/atau memanfaatkan sumber daya penambangan sehingga menghasilkan barang yang mempunyai nilai tambah termasuk jasa penambangan. Penambangan diklasifikasikan menjadi penambangan kecil, penambangan menengah dan penambangan besar.

Pengendalian kerusakan lingkungan berdasarkan Undang-Undang Nomor 32Tahun 2009 meliputi terkait dengandampak penambangan batu bata terrhadapkondisi fisik lingkungan masyarakt di Desa Kontumereadalah yang meliputi aspek fisik, kimiadan hayati adalah sebagi berikut. (1)Pencegahan, meliputi: melakukan Kajianlingkungan hidup strategis tentang dampakyang ditimbulkan terkait denganmenurunnya kualitas lingkungan hidup, Baku mutu lingkungan, Kriteria Bakukerusakan lingkungan, perizinan, danAMDAL. (2) Penanggulangan meliputipemberian informasi peringatan pencemaran atau pengisolasian kerusakan lingkungan, penghentian sumber pencemaran. (3) Pemulihan, meliputi : penghentian sumber pencemaran dan pembersihan pencemaran, rehabilitasi, remediasi, restorasi dan reklamasi.

Pengendalian kerusakan lingkungan berkenaan dengan penambangan batu bata di Desa Kontumere belum dilakukan Badan Lingkungan Hidup (BLH) dan Dinas Perizinan Kabupaten Muna belum berjalan sesuai dengan perundangan yang berlaku. Peran pemerintah dalam mencegah dan pengendalian kerusakan lingkungan terutama lembaga Badan Lingkungan Hidup (BLH) Kabupaten Muna harus melakukan pengendalian kerusakan lingkungan dilahan pertanian akibat penambangan batu bata dengan cara sosialisai kepada Camat dan Kepala Desa tentang pengendalian kerusakan dilahan pertanian, memberikan 
bantuan pengendalian kerusakan lingkungan dan rehabilitasi dilahan pertanian. Dinas Perizinan tidak melakukan pengendalian karena semua penambangan batu bata di Desa Kontumere berskala sangat kecil. Terkait dengan permasalahan diatas pengendalian kerusakan lingkungan selama ini belum berjalan maksimal dikarenakan adanya beberapa kendala sebagai berikut. (1) Kurangnya sosialisasi yang dilakukan oleh Camat dan Kepala Desa kepada penambang batu bata dan nasyarakat di Kecamatan Kabawo Kabupaten Muna. (2) Kurangnya anggaran dana untuk pelaksanaan pengendalian kerusakan lingkungan lahan pertanian di Desa Kontumere Kecamatan Kabawo Kabupaten Muna. (2) Adanya benturan kepentingan dengan instansi lain sehingga dana anggaran pengendalian kerusakan lingkungan yang dilakukan BLH Kabupaten Muna keluarnya tidak sesuai dengan waktu yang ditentukan.

Semua penambang batu bata di Desa Kontumere Kecamatan Kabawo Kabupaten Muna tidak memilki Tanda Daftar Penambangan, sehingga Dinas Perizinan Kabupaten Muna tidak dapat melakukan pengawasan terhadap penambangan batu bata di Kecamatan Kabawo.

\section{Dampak Kesehatan Masyarakat Terhadap Penambangan Batu Bata di Desa Kontumere.}

Di Desa Kontumere Kecamatan Kabawo jumlah pengrajin batu bata terus mempengaruhi perkembangan ekonomi masyarakat dan umumnya tidak menghilangkan pekerjaan utama mereka sebagai petani, sebagaimana yang di ungkapkan oleh Bapak La Marruwia salah satu pemilik penambangan batu bata di
Desa Kontumere Kecamatan Kabawo Kabupaten Muna.

Kegiatan dalam pengelolaan sumber daya alam banyak yang mengakibatkan kerusakan lingkungan dan ekosistem. Untuk mengetahui kerusakan lingkungan iperlukan adanya kriteria baku mutu lingkungan. Salah satu kerusakan lingkungan yang terjadi berada di wilayah Desa Kontumere di salah satu Kecamatan yaitu Kecamatan Kabawo. Kerusakan lingkungan hidup diakibatkan penambangan tanah di lahan pertanian untuk kegiatan penambangan batu bata.

Tidak hanya itu saja semenjak adanya kegiatan pengolahan sumber daya alam ini dapat mempengaruhi kesehatan masyarakat di wilayah penambangan batu bata, terutama pada saat proses pembakaran batu bata, asap yang dihasilkan dari pembakaran kayu itu ternyata berbahaya bagi kesehatan, bahwa partikel tak terlihat yang terhirup ke dalam paru-paru dari asap kayu bakar dapat menimbulkan beberapa dampak yang merugikan kesehatan.

Partikel udara di desa dan asap kayu bakar murni cenderung menjadi yang paling berpotensi bahaya - karena ukuran partikel ini cukup kecil sehingga terhirup hingga ke bagian terdalam dari paru-paru. Selain itu, asap kayu bakar mengandung kadarhidrokarbon aromatik polisiklik (PAH) yang lebih tinggi. Ketika diuji pada kultur sel manusia, asap murni dari kayu bakar ini juga menyebabkan kerusakan lebih pada materi genetik (DNA), lebih menyebabkan peradangan, dan mempunyai aktivitas lebih besar dalam membangkitkan gen yang dikaitkan dengan penyakit.

Dari hasil pembahasan diatas dapat diketahui bahwa dampak kesehatan terhdap penambangan batu bata bagi msayarakat di 
Desa Kontumere, sangat berbahaya, peran pemerintah setempat sangata penting untuk memperhatikan penambangan batu bata bagi kehatan.

\section{PENUTUP}

Kesimpulan

Berdasarkan hasil penelitian dan pembahasan tenatang dampak penambangan batu bata terhadap kondisi fisik lingkungan masyarakat Desa Kontumere Kecamatan Kabawo dapat ditarik kesimpulan sebagai berikut:

Gambaran dampak penambangan batu bata terhadap kondisi fisik lingkungan masyarakat Desa Kontumere Kecamata Kabawo, dimana kondisi fisik lingkungan masyarakat Desa Kontumere disekitaran penambangan batu bata yaitu;

1. Asap akibata pembakaran batu bata dapat mencemari udara dimana proses pembakaran menggunakan kayu bakar, proses pembakaran ini meningkatkan polusi udara (NOx dan $\mathrm{CO}^{2}$ ) disekitar lokasi penambangan batu bata.

2. pada musim hujan lubang bekasi galian penambangan batu bata akan digenangi air hujan dan dapat mengakipatkan erosi atau longsor.

3. menurunya zat kimia tanah dan pencemaran udara dan bayaknya lahan tidak memiliki vegetasi penutup lahan dapat merubah struktur tanah dan wilayah tersebut akan semakin kering.

2. Saran

Dari kesimpulan di atas maka penulis mengajukan beberapa saran antara lain sebagai berikut. (1) Perlu adanya kajian lingkungan hidup strategismengenai dampak lingkungan yangditimbulkan oleh
BLH Kabupaten Munasehingga dapat memberikan arahan dankebijakan terkait dengan izinpenambangan batu bata. (2) Dalammelakukan kegiatan penambangan batubata, pihak penambang perlumemperhatikan pengelolaan lingkungansecara terpadu agar tidak berdampak burukpada aspek fisika, kimia dan biologi demimenuju pembangunan dan kualitas hidupyang berkelanjutan. (3) Perlu dilakukanpenelitian lanjutan tentang seberapa besar manfaat penambangan batu bata dilahannon pertanian dan jika dijadikan lahanpertanian.

\section{DAFTARPUSTAKA}

Astwa, I., M., B., dan Sutarjo, 2006. Analisis Dampak Penambangan Batu Kapur Terhadap Lingkungan di Kecamatan Nusa Penida. Jurnal Ilmu Lingkungan. Volume 1. Nomor 1. Halaman $24-26$ Universitas Negeri Yogyakarta. Yogyakarta.

Asri, 2014. Dampak Darai Penambangan Galian di Desa Tanjung Kecamatan Koto Kampar Hulu Kabupaten Kampar. Jurnal Online Mahasiswa Universitas Riau.

Ahyari, A. 1986. Manajemen Produksi Perencanaan Sistem Produksi. BPFE. Yogyakarta.

Alamprabu, Djayawarman. 2007. Pembangunan Pertanian Berkelanjutan Dengan Pertanian Organik. Direktorat perlindungan perkebunan.

Basri, H. 2009. Analisis Faktor Yang Mempengaruhi Alih Fungsi Lahan Pertanian di Kabupaten Demak. Antara Jaya Press. Demak.

Nofi Rahmawati, La Ode Nursalam 
Elly M. Setiadi dalam Rusdiana, 2012. Analisis Mengenai Dampak Lingkungan. University Gadjah Mada Press. Yogyakarta.

Harman, 2007. Identifikasi Alih Fungsi Lahan Pertanian dan Kondisi Sosial Ekonomi Masyarakat Daerah Pinggiran di Kecamatan Gunungpati. Skripsi. Tugas Akhir tidak diterbitkan, Jurusan Perencanaan Wilayah dan Kota, Fakultas Teknik Universitas Diponegoro, Semarang.

Hardjasoemantri, Koesnadi. 2002. Hukum Tata Lingkungan. Yogyakarta: Gadjah Mada University Press.

Kartono, Kartini. 1989. Psikologi Abnormal dan Abnormalitas Seksual. Bandung: PT. Mandar Maju

Leavit, H.J (Terjemahan Muslichah Zakarsi). 1997. Psikologi Manajemen. Jakarta : Penerbit Erlangga .

Moekijat, 1995, Perencenaan dan Pengembangan karier pegawai, cetak 3, Remaja Rodaskarya, Bandung.

Nursia, dan Harudu. 2016. Dampak Penambangan Batu-Bata Terhadap Degradasi Lingkungan di Kelurahan Kolasa, Kecamatan Parigi, Kabupaten Muna. Jurnal Pendidikan Geografi. Volume 1. Nomor 1. Universitas Halu Oleo, Kendari. Halaman 14 - 16

Ramli. 2007. Sumberdaya Alam Untuk Pembangunan Nasional. Jakarta. Ghalia Indonesia. 